\title{
Quo Vadis EU Investment Law and Policy? The Shaky Path Towards the International Promotion of EU Rules
}

\begin{abstract}
Szilárd GÁsPÁr-SZILÁGYI ${ }^{\star}$
Following the Lisbon changes to the EU's Common Commercial Policy (CCP), the path was set for the EU to conclude international agreements that cover the protection of foreign direct investment and to participate in international investment law (IIL) as a creator and promoter of norms. Nonetheless, recent political and legal events might jeopardize the workability and coherence of the emerging EU investment law and policy. In light of this, this article first aims to contribute to the existing discussion on the ways in which the EU can export its norms externally and provides a conceptual understanding of the often-used term of 'convergence' and how the EU might induce some level of convergence of IIL norms. Secondly, the article has a sceptical undertone as to whether the EU can become an IIL rule-promoter and whether it can induce some level of convergence of IIL norms. Whilst the possibility is there, the multilateral and diffused nature of investment law, the presence of strong international actors with their own agendas, the domestic contestation of investor-state dispute settlement, and the important role of the Court of Justice might hamper the EU's attempt to become a major influencer of IIL norms
\end{abstract}

\section{INTRODUCTION}

The EU is a relatively new player in the field of International Investment Law (IIL). Following the Lisbon amendments to the EU's Common Commercial Policy (CCP), ${ }^{1}$ the path was set for the EU to conclude international agreements that covered the protection of foreign direct investment ${ }^{2}$ and to participate in IIL

\footnotetext{
* Postdoctoral Fellow, PluriCourts - Centre for the Study of the Legitimate Roles of the Judiciary in the Global Order, University of Oslo. Email: szilard.gaspar-szilagyi@jus.uio.no. This work was partly supported by the Research Council of Norway through its Centres of Excellence funding scheme, project number 223274. The author would like to thank Elaine Fahey (City University London) and the participants of the 'Modelling Convergence(s) and Divergence(s) of EU in the World' Workshop, held at City University London on 23 November 2017.

1 TFEU, Art. 207(1). See A. Dimopoulos, The Effects of the Lisbon Treaty on the Principles and Objectives of the Common Commercial Policy, 15 Eur. Foreign Aff. Rev. 153-170 (2010); C-H. Wu, Foreign Direct Investment as Common Commercial Policy: EU External Economic Competence After Lisbon, in EU External Relations Law and Policy in the Post-Lisbon Era 375-400 (P. J. Cardwell ed., Springer-Asser 2012); The Anatomy of the (Invisible) EU Model BIT Marc Bungenberg and August Reinisch (Guest Editors, Special Issue), 15(3-4) J. World Inv. \& Trade, Special Issue (2014).

2 In the pre-Lisbon era, the EU, together with its Member States, concluded the Energy Charter Treaty, which includes an ISDS mechanism.
}

Gáspár-Szilágyi, Szilárd. 'Quo Vadis EU Investment Law and Policy? The Shaky Path Towards the International Promotion of EU Rules'. European Foreign Affairs Review 23, no. 02 (2018): 167-186.

(C) 2018 Kluwer Law International BV, The Netherlands 
as a creator and promoter of norms. Nonetheless, recent political and legal events might jeopardize the workability and coherence of the emerging EU investment law and policy.

With the above in mind, this article looks at the ways in which the EU can use/has used its Article 207 TFEU powers to promote its own rules and values in IIL, either bilaterally or multilaterally. It asks the question whether the EU can become a major IIL norm creator or promoter. As a response, the article argues that recent external and internal political, as well as legal constraints, call into question the EU's ability to act as a rule-promoter in IIL. This in turn can result in low levels of convergence of IIL norms towards EU norms or towards general norms, inspired by EU norms.

Regarding the structure, section 2 clarifies some of the terms used in the analysis and provides a short overview of the various ways in which the EU promotes its norms externally. Section 3 then looks at the current state of EU investment law and policy, considering various internal and external factors that influence the EU's ability to become a promoter of rules in IIL and its ability to achieve some level of convergence of IIL norms. Section 4 focuses on concluding remarks.

\section{HOW DOES THE EU PROMOTE ITS NORMS EXTERNALLY?}

\subsection{Clarifying some of the terms}

In 2002, prior to the Lisbon amendments, Manners identified five 'core' norms on which the EU rests: peace, liberty, democracy, rule of law, and human rights. To this, he added four 'minor' norms: social solidarity, anti-discrimination, sustainable development, and good governance. ${ }^{3}$ Article 3.5 TFEU now codifies these 'norms' and lays down a double constitutional obligation for the EU in its relations with the outside world. Firstly, the EU shall 'uphold' and 'promote' its values and interests. Secondly, it shall 'contribute' to the achievement of major global objectives, such as peace, security, solidarity, sustainable development, free and fair trade, the protection of human rights, etc. From the text of the article one can deduce that these obligations cover all types of EU 'relations' with the outside world, be they the setting-out of policy objectives, the creation of new treatybased rules and institutions, or actual, on the ground operations. Furthermore, they require the EU to act in a positive manner, either by actively encouraging the usage and dissemination of EU values ('promote') externally or by bringing about the achievement of major global objectives ('contribute').

\footnotetext{
J. Manners, Normative Power Europe: A Contradiction in Terms?, 40(2) J. Com. Mkt. Stud. 235-258, 242-243 (2002).
} 
The article restricts itself to the ways in which the EU can affect norms externally, either by promoting its own norms or by contributing to the creation of common norms. It uses a narrow understanding of the term 'norm', in the sense of norms found in hard law instruments such as international treaties, international decisions, etc. The dissemination of norms via soft law instruments will not be the focal point of the analysis. Furthermore, in the upcoming sections I will use the terms 'norms' and 'rules' interchangeably.

Moving on, international actors that wish to engage externally with each other are faced with a diverse set of legal rules. They can opt to keep the diversity of the rules between them as they are, or more often, to bring them closer together. Matta argues that international actors wishing to solve problems created by legal diversity can choose various options. These options can be placed on a scale that starts with the diversity of rules, continues towards approximation, convergence, harmonization, and ends in the unification of the rules. ${ }^{4}$ When looking at these processes, one must take into consideration the context in which they take place, the instruments used in the process, and the elements that need approximation. ${ }^{5}$ For example, the recent EU-Ukraine Association Agreement ${ }^{6}$ is set in the broader context of the European Neighbourhood Policy ('context'), which aims to create a circle of like-minded states surrounding the EU, by bringing lasting political, economic and judicial reforms in the partner countries ('instruments'), through the approximation of laws, standards or practices ('elements').

There is no clear line separating the concepts of convergence, approximation and harmonization. There is a lively academic debate on the exact meaning of these individual concepts. ${ }^{7}$ The article, however, does not wish to engage with this debate. Instead, it opts for the concept of convergence, in the sense of two or more things coming together. It also differentiates between two types of rule convergence, explained below: type A and type B convergence.

Type A convergence, as illustrated in Figure 1, implies an asymmetric movement; the norms of the 'weaker' party will move closer to the norms of the 'stronger' party. ${ }^{8}$ For the EU this means that the norms of a partner country,

4 A. Matta, Differentiating the Methods of Acquis Export: The Case of the Eastern Partners and Russia, in Legislative Approximation and Application of EU Law in the Eastern Neighbourhood of the European Union. Towards a Common Regulatory Space? 21-45, 24-26 (P. Van Elsuwege \& R. Petrov eds, Routledge 2014).

$5 \quad$ Ibid., at 25

6 Association Agreement between the European Union and its Member States, of the one part, and Ukraine, of the other part (2014).

See Matta, supra n. 4, at 25-28 and his references to other authors.

8 'Strength' here is not defined in military terms, but refers to the size of the market, economic strength, etc. The EU can use the size of its market as a bargaining tool in negotiations with countries who want to get access to that market. 
such as Vietnam or Canada, will move closer to the more authoritative 'EU norms'. Type A convergence will mostly happen in the bilateral context, in which there is a power imbalance in favour of the EU. This does not mean that the partner country cannot become a norm-setter when concluding an agreement with a different country. For example, Canada can be seen as the weaker party in the context of the Comprehensive Economic and Trade Agreement (CETA), but the stronger party in case of the Canada-Benin investment agreement.

One could also debate whether Type A convergence in some cases might result in 'norm imposition' by the stronger party. Nevertheless, this type of convergence is easier to measure. For example, one can look at whether the stronger party uses its own model agreement as a template for the conclusion of the international agreement with the weaker party. If the resulting agreement follows the stronger party's model, then it is evident that the weaker party will follow the norms of the stronger one.

In investment law, the US or Canada often use model bilateral investment treaties (BITs) as a basis for the conclusion of similarly/identically worded BITs with third countries from Latin America or Africa, among others. ${ }^{9}$ Closer to home, the EU/EC had used the similarly/identically worded Europe Agreements to induce normative changes in the candidate Central and Eastern European countries. However, an 'express' model agreement, designated as such, does not necessarily have to exist. For example, in the first years of its investment policy the EU Commission had expressly renounced the idea of a 'one-size-fits-all' model for international investment agreements (IIAs). ${ }^{10}$ The reason was that the EU had to take into account 'each specific negotiating context' and the 'interests of [EU] stakeholders as well as the level of development' of the partner countries. ${ }^{11}$ Nonetheless, several years later some academics had argued that an 'invisible' model EU BIT exists. ${ }^{12}$ A good example for this is how the model Investment Court System (ICS) proposed during the negotiations of the Transatlantic Trade and Investment Partnership (TTIP) found its way into the CETA with Canada and the EU-Vietnam free trade

\footnotetext{
$9 \quad$ See US Model BIT (2004, 2012); Canadian Model Foreign Investment Protection Agreement (FIPA, 2004). The Canadian FIPA was used as a model for a string of new agreements with African countries (Benin, Tanzania, Cameroon, Nigeria, Senegal, Mali, Cote d'Ivoire, Burkina Faso, and Guinea). See R. Willard \& S. Morreau, The Canadian Model BIT - A Step on the Right Direction for Canadian Investment in Africa? (2016), http://kluwerarbitrationblog.com/2015/07/18/the-canadian-model-bita-step-in-the-right-direction-for-canadian-investment-in-africa/ (accessed 9 Apr. 2018).

10 See European Commission Communication, Towards a Comprehensive European International Investment Policy 6, COM (2010) 343 final (7 July 2010), http://trade.ec.europa.eu/doclib/docs/2010/july/ tradoc_146307.pdf (accessed 9 Apr. 2018).

11 Ibid.

12 See Special Issue, supra n. 1.
} 
agreement (FTA). Furthermore, the EU Commission renegotiated the recently split EU-Singapore FTA to include the ICS model in the Investment Protection Agreement. ${ }^{13}$ The Commission's shift to an 'invisible model BIT' is a result of the contestation of investor-state dispute settlement (ISDS) in several EU Member States. This translated into the need to ensure that all new EU trade agreements with investment chapters meet certain basic requirements demanded by civil society, such as increased transparency, the protection of the host State's right to regulate, or the reform of ISDS mechanisms.

Type B convergence appears in Figure 2. One could even use the term 'true convergence', in the case of which many different norms head towards one common norm. This type of convergence will mostly occur in the multilateral setting, where one actor cannot impose its own norms on other actors. The most it can do is influence the commonly accepted norms. Type B convergence could also occur in a bilateral setting, between two equal parties that are not willing to follow the norms imposed by one of them.

In the case of type B convergence, it is also more difficult to measure the influence of one of the parties. First, the negotiating histories for multilateral agreements are often incomplete or non-existent. Thus, it is hard to figure out which party influenced the creation of a specific rule. Second, even if one can identify one of the parties as the main catalyser behind the adoption of a new set of rules, the differences between the originally proposed rules and those commonly agreed upon can be great, thus minimizing the influence of the initiator.

Figure 1 Type A Convergence

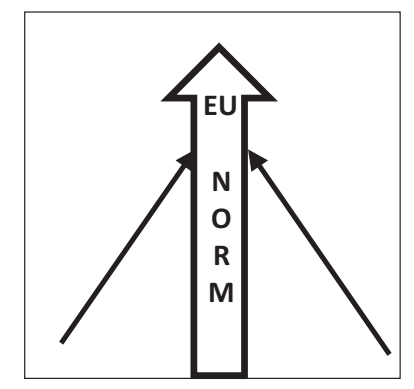

13 European Commission, EU-Singapore Trade and Investment Agreements (Authentic Texts as of Apr. 2018) goo.gl/Ppe8wC http://trade.ec.europa.eu/doclib/press/index.cfm?id=961 (accessed 2 July 2018). 
Figure 2 Type B Convergence

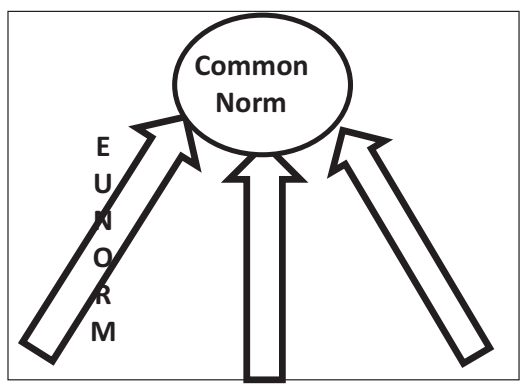

One also needs to look at 'what' is converging towards 'what'. Are various national/internal norms converging towards an international/supranational norm?${ }^{14}$ Are several international norms converging towards another international norm? Alternatively, are national norms in one entity converging towards the national norms of another entity via an international agreement? In the EU context, Matta differentiates between the internal approximation of EU Member State norms and the export of EU norms, achieved for example through legislative approximation in the partner countries. ${ }^{15}$ Larik mentions 'top-down Europeanization' as a process 'of national adaptation to the requirements of EU membership'. ${ }^{16}$ However, these examples refer to some form of changes brought to the internal norms of EU Member States, candidate states or the partner countries. The article, on the other hand, is concerned with international rules/norms and their convergence. In other words, how can the IIL norms of other countries converge towards IIL norms of the EU, or how can the EU contribute to the convergence of various IIL norms towards common IIL norms?

\subsection{A multitude of eU methods}

The EU has actively pursued its Article 3.5 TFEU objectives, both bilaterally and multilaterally. ${ }^{17}$ It defends and promotes its interests and values in various international organizations that accept its membership (World Trade Organization, Food and Agriculture Organization), it exports its norms in preferential trade,

14 E.g. Larik talks about 'bottom-up Europeanization', according to which Member States 'project' their national preferences to the EU level. See J. Larik, Foreign Policy Objectives in European Constitutional Law 267 (Oxford University Press 2016).

15 Matta, supra n. 4, at 26 and 34.

16 Larik, supra n. 14, at 266.

17 See M. Cremona, The Union as a Global Actor: Rules, Models and Identity, 41 Common Mkt. L. Rev. 556, 553-573 (2004). 
cooperation or association agreements or, it acts as the galvanizer behind pathbreaking multilateral agreements (Paris Climate Agreement, Rome Statute of the ICC) or multilateral institutions (UN Ombudsperson). As Cremona notes, the EU not only acts as a 'rule generator', but also as a regional stabilizer (albeit with limited success in recent years). ${ }^{18}$

Writing fifteen years ago Manners argued that due to the EU's unique nature, its relationship with the outside world should not be seen through the more traditional, state like models, such as 'military' 19 or 'civilian power'. Instead, the $\mathrm{EU}$ acts as a 'normative power'. ${ }^{20}$ It disseminates its norms through various means. First, the EU can unintentionally diffuse its norms to other political actors (contagion). The EU can also use various information channels to diffuse its norms (informational diffusion), it can institutionalize its relationship with a third country (procedural diffusion), and it can spread its norms via its physical presence in third countries (overt diffusion). Furthermore, it can use the 'carrot and stick' method to induce EU infused changes in the partner country in exchange of material support (transference), or it can impact through softer means such as cultural diffusion. ${ }^{21}$ As the next sections will illustrate, when it comes to the diffusion of IIL norms, the first three methods are most adequate. The EU has thus far included its investment protection standards and the ICS in far-reaching trade and investment agreements (procedural diffusion) and has published many policy documents on how it seeks to reform investment law (informational diffusion). It might also happen that in case of a successful EU ICS model, other countries will follow it (contagion).

It can be argued that in the bilateral setting, the EU mainly promotes Type A convergence, by making other, predominantly weaker international partners accept the EU's norms. This has especially been the case with regard to the EU's neighbours. The EU's network of Partnership and Cooperation Agreements PCAs and more recently Association Agreements with Deep and

18 Ibid., at 557-560. It is debatable whether in the last six to seven years the EU truly acted as a 'stabilizer' in its Neighbourhood. One needs to look at the events that unfolded/are unfolding following the 'Arab Spring' or the crisis in Eastern Ukraine and Crimea.

19 Z. Radosavljevic, EU Takes Step Towards Closer Defence Cooperation Euractiv (13 Nov. 2017), http:// www.euractiv.com/section/defence-policy/news/eu-takes-step-towards-closer-defence-cooperation/ ?utm_term=Autofeed $\&$ utm_campaign=Echobox\&utm_medium=Social\&utm_source= Facebook\#link_time=1510555356 (accessed 9 Apr. 2018).

20 Nonetheless, sociologists have argued that there is a gap between the EU's self-perception as a normative power and the perception of the EU by other international actors. See D. Sicurelli, The EU as a Norm Promoter Through Trade. The Perceptions of Vietnamese Elites, 13 Asia Eur. J. 23-39 (2014). Kassoti also argues that there is a growing gap between the EU's rhetoric as a global promoter of values and realpolitik. See E. Kassoti, Between Völkerrechtsfreundlichkeit and Realpolitik. The EU and Trade Agreements Covering Occupied Territories, ItYBIL 139-170 (2016). For an overview of the EU's role as a 'normative' power through the lenses of multiple theories of international relations, see Larik, supra n. 14, Ch. 5.

21 Manners, supra n. 3, at 244-245. 
Comprehensive Trade Agreements, however, do more than just ensure that on the international level treaties incorporate rules that are predominantly EU inspired. Some level of convergence has also occurred in the partner countries' internal legal systems. For example, Petrov and Kalichinenko have demonstrated that, notwithstanding problems linked to the effectiveness and independence of the Russian and Ukrainian courts, the EU acquis has permeated the local courts, thanks to factors such as EU soft law instruments, the provision of technical and financial assistance, and the CJEU's favourable interpretation of EU law towards third country nationals. ${ }^{22}$

In the multilateral setting, the EU can mainly induce Type B convergence, by being the galvanizer behind a multilateral effort to create some form of 'common norms'. If there is not much opposition from more powerful contracting parties or a group of 'like-minded' states, then the EU can push forward a set of 'common norms' that is greatly influenced by its own norms and values. However, it is also possible that the opposition of other states will lead to the watering down of many EU inspired norms. Still, some level of convergence will occur, albeit one with less $\mathrm{EU}$ input. As mentioned, measuring the exact extent of the EU input in the multilateral setting can be difficult, due to the often-missing negotiating histories. Furthermore, it is also hard to quantify the importance of the EU's input in a commonly accepted set of rules. Nonetheless, the EU-inspired changes brought to the UN's Chapter VII sanctions regime is a good example of how the EU can induce some level of convergence, even in a multilateral organization to which it cannot formally accede. The Court of Justice's strong stance in the Kadi case to protect the right to fair trial, combined with the pressure of the EU and its Member States have resulted in the creation of the UN Ombudsperson, which introduces elements of fairness and transparency in the UN sanctions regime. ${ }^{23}$

\section{DID THE EU BITE OFF MORE THAN IT CAN CHEW?}

One would expect that given the EU's extensive normative influence in various fields of international law, it would also have a major influence on IIL norms. This influence would then lead to some level of convergence of IIL norms, either by making other treaty parties follow the EU's norms or by the EU contributing to the creation of a set of multilateral norms. Section 3 challenges this assumption. It first provides an overview of

22 R. Petrov \& P. Kalichenko, The Europeanization of Third Country Judiciaries Through the Application of the EU Acquis: The Cases of Russia and Ukraine, 60 Int'l \& Comp. L.Q. 325-353 (2011).

23 J. Wouters \& S. Duquet, The United Nations, the European Union and Multilateral Action Against Terrorism, in EU Management of Global Emergencies 359-395, 390-391 (I. Govaere \& S. Poli eds, Brill-Nijhoff 2014); C. Eckes, EU Restrictive Measures Against Natural and Legal Persons: From Counterterrorist to Third Country Sanctions, 51 Common Mkt. L. Rev. 869-906, 875-879 (2014). 
the major milestones in the short nine-year existence of the EU's investment law and policy, followed by a discussion of several internal and external factors that cast a shadow over the EU's potential to induce the convergence of IIL norms.

\subsection{THE CUMBERSOME ROAD TO AN EU INVESTMENT LAW AND POLICY}

One can divide the EU's post-2009 experiences with investment law and policy into three major periods up until the writing of this article: an initial period of modest reform, an intermediate period marked by a push to reform existing IIL norms, followed by more recent backtracking.

During the initial period, from late 2009 until early 2013, the EU Commission's approach to the substantive rules of investment protection and ISDS was neither radical nor complete continuity was advocated; the overall direction 'seemed to be one of modest reform, centring on attempting to fine-tune existing approaches to ISDS' ${ }^{24}$ During this period, the Commission had expressly renounced the idea of a 'one-size-fits-all' model for IIAs. ${ }^{25}$ Furthermore, it was satisfied with twitching existing IIL norms found in major agreements such as NAFTA. For example, the Commission's 2010 Communication 'towards a comprehensive European international investment policy' includes very general terms ${ }^{26}$ that are quite favourable to investors and investments. ${ }^{27}$ The Communication only succinctly addresses some of the substantive standards of investment protection, such as national treatment or fair and equitable treatment (FET), and shortly lays out the main guidelines for ISDS, such as transparency and quasi-permanent arbitrators. ${ }^{28}$ Following the Commission's Communication, the European Parliament issued its 2011 Resolution $^{29}$ that, among others, called upon the Commission to include in all future EU FT(I)As specific clauses laying down the right of the treaty parties to regulate in the public interest. ${ }^{30}$ The 2012 leaked draft proposals of the EU

24 C. J. Tams, Procedural Aspects of Investor-State Dispute Settlement: The Emergence of a European Approach, 15 J. World Inv. \& Trade 591, 585-611 (2014).

25 See European Commission Communication, supra n. 10. Fns 20-29 also appear in various forms in S. Gáspár-Szilágyi, Binding Committee Interpretations in the EU's New Free Trade and Investment Agreements, 2 Eur. Invest. L. Arb. Rev. 90-133 (2017).

26 A. Reinisch, Putting the Pieces Together ... an EU Model BIT?, 15 J. World Inv. \& Trade 681, 679-704 (2014).

27 See European Commission Communication, supra n. 10, at 5-9 ' [the] international investment policy needs to better address investor needs from the planning to the profit stage or from the pre- to the post-admission stage'. This is slightly counter-balanced with the need to ensure that 'a common investment policy should also be guided by the principles and objectives of the Union's external action .... including the promotion of the rule of law, human rights and sustainable development'.

28 Ibid., at 8-10.

29 European Parliament, Resolution of 6 April 2011 on the Future European International Investment Policy, P7-TA(2011) 0141, http://www.europarl.europa.eu/sides/getDoc.do?pubRef=-//EP//NONSGML +TA+P7-TA-2011-0141+0+DOC+PDF+V0//EN (accessed 9 Apr. 2018).

$30 \quad$ Ibid., point 25. 
Commission for future ISDS provisions ${ }^{31}$ did not depart from the mainstream models found in NAFTA, or US and Canadian IIAs. It only provided for ad hoc tribunals established under various arbitration rules (Article 8); it did not provide for appellate review, but it did mention the right of the treaty parties to provide binding interpretations of the agreements (Article 9.2). It also incorporated the UN Commission on International Trade Law (UNCITRAL) rules on transparency (Article 11).

The second period spans roughly from 2013 to late 2016/early 2017. In 2013, the EU Commission's approach came under growing pressure from NGOs and civil society. ${ }^{32}$ This resulted in the 2014-2015 Public Consultation on ISDS under TTIP that evidenced a clear split between the business world and civil society as to the necessity of ISDS. ${ }^{33}$ Following the backlash from civil society, the EU Commission (together with the European Parliament) took upon itself the role to address and possibly solve ${ }^{34}$ in the new FTIAs some of the major issues ${ }^{35}$ that have led to the contestation of IIL and ISDS. This initiative resulted in the famous November 2015 Proposal for ISDS under TTIP, which in an altered form found its way into CETA (renegotiated in early 2016), the EU-Vietnam FTA, and the EU-Singapore Investment Protection Agreement.

Following the 2015 Proposal, the new bilateral FT(I)As introduced significant reforms on three different levels: democratic, substantive and procedural. Looking at the democratic parameters, they include advanced transparency rules that incorporate and go beyond the UNCITRAL rules on transparency and allow third party intervention. ${ }^{36}$ From an institutional/procedural perspective the FTIAs would set up their own standing ICS with two-tier adjudication, the investors would not appoint their own arbitrators, ${ }^{37}$ and it prohibits the 'double'

31 The document is available at World Trade Online and requires registration, https://insidetrade.com/ daily-news/eu-draft-text-isds-contains-similarities-differences-us-approach. The PDF document consists of three parts in the following order: the June 2012 revised draft of the Commission, the Commission's explanations summarizing revisions and the initially leaked May 2012 document. See also Tams, supra n. 24, fn. 40 (accessed 9 Apr. 2018).

32 European Commission, Fact Sheet. Investment Protection and Investor-to-State Dispute Settlement in EU agreements (Nov. 2013), http://trade.ec.europa.eu/doclib/docs/2013/november/tradoc_151916.pdf (accessed 9 Apr. 2018).

33 European Commission, Online Public Consultation on Investment Protection and Investor-to-State Dispute Settlement (ISDS) in the Transatlantic Trade and Investment Partnership (TTIP), SWD (2015) 3 final, http://trade.ec.europa.eu/doclib/docs/2015/january/tradoc_153044.pdf (accessed 9 Apr. 2018).

34 EU Commission, Investment in TTIP and Beyond - The Path to Reform, Concept Paper (2015), http:// trade.ec.europa.eu/doclib/docs/2015/may/tradoc_153408.PDF (accessed 9 Apr. 2018).

35 See G. Van Harten, Public Statement on the International Investment Regime, http://www.osgoode.yorku. ca/public-statement-international-investment-regime-31-august-2010/ (accessed 9 Apr. 2018).

36 See S. Gáspár-Szilágyi, Transparency, Investment Protection and the Role of the European Parliament, 2 Eur. Invest. L. Arb. Rev. 371-411 (2017).

37 The EU-Singapore FTA is the exception, until the EU Commission renegotiates its ISDS provisions in order to include the new ICS. 
hatting of arbitrators. ${ }^{38}$ Nevertheless, the new FTIAs, just as the existing Member State BITs, do not include an 'exhaustion of local remedies' rule. Regarding the substantive parameters, the new FTIAs include more clearly worded provisions on investment protection, they expressly acknowledge the contracting parties' right to regulate, ${ }^{39}$ and the contracting parties via their membership in treaty committees retain the power to give binding interpretations of the FTIAs. ${ }^{40}$

The EU's assertive approach could/can also be seen on the multilateral level. The EU Commission decided to join the growing trend of increasing the transparency of ISDS proceedings and became an active participant in the UNCITRAL working groups that preceded the adoption of the 2013 UNCITRAL Transparency Rules in Treaty-Based Investor-State Arbitration (UNCITRAL TR). ${ }^{41}$ Furthermore, the EU has recently rolled out its plans to set up a Multilateral Investment Court (MIC), in order to create a more 'transparent, coherent and fair' system of settling investor-state disputes. ${ }^{42}$ In July 2017 , UNCITRAL agreed to discuss possible multilateral approaches to ISDS ${ }^{43}$ and in March 2018, the Council issued the negotiating directives for the MIC. ${ }^{44}$

One could thus assume that following a somewhat slow and idle start, the EU is becoming a 'shaper' of the international investment regime. ${ }^{45}$ It is actively concluding FTAs with reformed investment chapters and ISDS, based on its own model clauses. Therefore, one could argue that Type A convergence is happening on the bilateral level through the 'promotion' of EU norms, towards which the IIL norms of the other parties are moving closer to. Furthermore, the EU is initiating multilateral responses to some of the legitimacy concerns faced by IIL that can result/have resulted in Type B convergence, towards common IIL norms partially inspired by EU norms.

I would have fully agreed with these statements in December 2016. At the beginning of 2018, however, one can argue that the EU's investment law and

38 CETA, Arts 8.27.4 and 8.28.4; EU-Singapore, Art. 9.28.6; EU-Vietnam, Ch. II, s. 3, Arts 12.4 and 13.7; TTIP Proposal, s. 3, Arts 9.4 and 10.7.

39 CETA, Art. 8.9; TTIP Proposal, s. 3, Art. 2.

40 Gáspár-Szilágyi, supra n. 25.

41 See E. Shirlow, Dawn of a New Era? The UNCITRAL Rules and UN Convention on Transparency in Treaty-Based Investor-State Arbitration, 31(3) ICSID Rev. 622-654, 625-626 (2016).

42 EU Commission, DG Trade, The Multilateral Investment Court Project, http://trade.ec.europa.eu/ doclib/press/index.cfm?id=1608 (accessed 9 Apr. 2018).

43 EU Commission, State of the Union. A Multilateral Investment Court, http://trade.ec.europa.eu/doclib/ docs/2017/september/tradoc_156042.pdf (accessed 9 Apr. 2018).

44 Council of the EU, Negotiating Directives for a Convention Establishing a Multilateral Court for the Settlement of Investment Disputes (20 Mar. 2018).

45 For a discussion on the role of States in shaping the overall investment law regime, see M. Langford, D. Behn \& O. K. Fauchald, Tempest in a Teapot? The International Investment Regime and State Backlash, in The Changing Practices of International Law: Sovereignty, Law and Politics in a Globalising World (T. Gammeltoft-Hansen \& T. E. Aalberts eds, Cambridge University Press 2016). 
policy has entered a third phase, one of possible backtracking from the previous impetus, an upcoming period laden with hardship, and bleaker prospects for the convergence of IIL norms. The next sections will elaborate this idea further.

\subsection{EXternal CONSTRAints}

Sections 3.2 and 3.3 will elaborate on the final thoughts of section 3.1. Why is it that one can speak of a third phase of the EU's investment policy in which the EU's role as a shaper of IIL might not fully materialize? What internal and external factors can contribute to this eventuality?

\section{2[a] Multilateralism in International Investment Law}

One of the greatest achievements of the EU in IIL and possibly one of the greatest achievements within this field would be the creation of a MIC. According to the Commission, such a court 'should be formed by highly qualified permanent and full-time judges, completely independent of investors and states'. ${ }^{46}$ Furthermore, the MIC would allow either party to appeal the decision and it would be transparent. ${ }^{47}$ Thus, the principles that guided the creation of the ICS would also guide the EU's proposal for a MIC. Nonetheless, the Commission knows all too well that the MIC cannot follow the EU's proposal entirely, because other international actors would influence the final version.

The problem is not the extent to which the future MIC would follow the EU's proposal. Instead, the problem is whether the creation of a MIC is possible at all. Investment law as a field of international law rests on over 3,000 agreements, consisting of BITs, preferential trade agreements (PTAs) with investment chapters, ${ }^{48}$ and a handful of regional agreements, such as NAFTA or the Energy Charter Treaty. With all their differences, most IIAs use standards and principles that nowadays are broadly accepted as appropriate standards for investor-state relations. ${ }^{49}$ Nevertheless, multilateral efforts in investment law manifest themselves differently than bilateral ones. Whilst, specific reciprocity characterizes IIL bilateralism, which usually manifests itself in rules that favour the interests of the more powerful, multilateralism 'is not about the imposition of rules that create one-sided

EU Commission, supra n. 43.

47 Ibid.

48 See M. Usynin \& S. Gáspár-Szilágyi, The Growing Tendency of Including Investment Chapters into PTAs, 48 NYIL 267-304 (2017-2018).

49 S. W. Schill, Ordering Paradigms in International Investment Law: Bilateralism - Multilateralism Multilateralization, in The Foundations of International Investment Law (Z. Douglas, J. Pauwelyn \& J. E. Viñuales eds, Oxford University Press 2014) [emphasis added]. 
benefits for a hegemon to the detriment of several other states ${ }^{50}$ Previous efforts to create some form of multilateral understanding in investment law, such as the 1998 OECD Multilateral Agreement on Investment, all failed. One could argue that the UNCITRAL $\mathrm{TR}^{51}$ are a testimony to the possibility to reach a multilateral result. However, these rules have a lesser impact than a potential MIC would have. Furthermore, the Mauritius Convention, on the application of the UNCITRAL TR to investment treaties concluded before 1 April 2014, is witnessing slow ratification. ${ }^{52}$

One also needs to look at the broader political context and whether major players, such as India, China or the US would get on board. Following the 2016 US Presidential elections, the Trump Administration does not have a favourable attitude towards large trade and investment law initiatives, evidenced by the US exit from Trans-Pacific Partnership (TPP) and the current frozen negotiations of TTIP. In Asia, India is striving to shed its past practice of being a rule-taker. Its recent investment law practice includes new investment provisions that are more favourable to the state and evidence broader substantive coverage than its earlier, western influenced BITs. ${ }^{53}$ China is also striving to become a rule-maker and not a rule-taker. Its recent One-Belt-One-Road initiative would also include its own ISDS mechanism, shaped by Asian-style dispute settlement. ${ }^{54}$ This broader political climate would make the creation of an EU-inspired MIC quite unlikely, since the EU does not hold 'the monopoly of normative power'. ${ }^{55}$

In conclusion, the success of the EU in creating a MIC, inspired by its own values and norms, could be minimal, given the past multilateral failures to regulate IIL and the need to compromise in order to meet the demands of other ambitious partners that are already rule-shapers or are becoming ruleshapers. Therefore, any type of IIL rule convergence (Type B) on the multilateral level that will be a result of the EU's actions is still a matter of speculation

UNCITRAL, Status. UN Convention on Transparency in Treaty-Based Investor-State Arbitration, https:// goo.gl/pyuuUP (accessed 9 Apr. 2018). Thus far, only Canada, Cameroon, Mauritius, and Switzerland have ratified it. Furthermore, only twenty-two states have signed it, a handful of which are EU Member States.

53 P. Ranjan, Comparing Investment Provisions in India's FTAs with India's Stand-Alone BITs: Contributing to the Evolution of New Indian BIT Practice, 16 J. World Inv. \& Trade, 899-930, 928-929 (2015).

54 V. Bath, 'One Belt, One Road' and Chinese Investment, Oxford Business Law Blog (2017), https:// www.law.ox.ac.uk/business-law-blog/blog/2017/01/\%E2\%80\%98one-belt-one-road $\%$ E2\%80\%99and-chinese-investment (accessed 9 Apr. 2018).

55 Sicurelli, supra n. 20, at 26.
} 


\section{2[b] Strong vs Weak/Strong Bilateral Parties With/Without Own IIL Norms}

In a bilateral setting, one must consider two other factors: the power balance between the parties, as well as whether both parties have 'their own' IIL norms. The following examples in Table 1 shall illustrate how these two factors could influence the type of convergence that might occur.

Table 1. Strong vs Weak Bilateral Parties

\begin{tabular}{|c|c|c|c|c|}
\hline & Party 1 & Party 2 & Type A Conv & Type B Conv \\
\hline $\begin{array}{l}\text { Example } 1 \\
\text { Has own norms? }\end{array}$ & $\begin{array}{l}\text { Strong } \\
\text { Yes }\end{array}$ & $\begin{array}{l}\text { Weak } \\
\text { No }\end{array}$ & $\begin{array}{l}\text { Rather Norm } \\
\text { Imposition }\end{array}$ & $\begin{array}{l}\text { Very low } \\
\text { chances, } \\
\text { 'contagion' } \\
\text { possible }\end{array}$ \\
\hline $\begin{array}{l}\text { Example } 2 \\
\text { Has own norms? }\end{array}$ & $\begin{array}{l}\text { Strong } \\
\text { Yes }\end{array}$ & $\begin{array}{l}\text { Weak } \\
\text { Yes }\end{array}$ & High chances & Low chances \\
\hline $\begin{array}{l}\text { Example } 3 \\
\text { Has own norms? }\end{array}$ & $\begin{array}{l}\text { Strong } \\
\text { Yes }\end{array}$ & $\begin{array}{l}\text { Strong } \\
\text { Yes }\end{array}$ & Very low chances & $\begin{array}{l}\text { Possible with } \\
\text { spill over effects }\end{array}$ \\
\hline
\end{tabular}

In the first example, a strong party with its own IIL norms is negotiating an agreement with a weaker party, without its own IIL norms. An example is the EU-Vietnam FTA in which the EU is the 'strong' party, ${ }^{56}$ with its own model IIL norms, and Vietnam is the 'weaker' party that in previous IIAs has mostly accepted the IIL norms of other, stronger parties. ${ }^{57}$ Since Vietnam has no existing model IIL norms of its own, one could argue that this is mainly ${ }^{58}$ a situation of "norm imposition' by the stronger party on the weaker one. When it comes to Type B convergence, the chances of it occurring are very low, since it is highly unlikely

56 Sicurelli's research on the perception of the EU as a normative power by Vietnamese elites paints a more balanced picture. The 'EU was criticized for the lack of coherence in its trade and developments policies, its interference in the government's decisions on politically sensitive issues and its internal division on human rights clauses'. See Sicurelli, supra n. 20, at 25.

57 Vietnam has concluded BITs with most EU Member States. These are the BITs with France (1994); Denmark (1994); Italy (1994); Poland (1994); Sweden (1994); Hungary (1995); Netherlands (1995); Romania (1995); Latvia (1996); Austria (1996); Bulgaria (1998); Germany (1998); Czech Republic (1998); UK (2002); Lithuania (2003); Finland (2009); Slovakia (2011); Spain (2011). The BITs with Greece (2008 signed); Estonia (2009 signed) have yet to enter into force. See EU-Vietnam FTA, Annex (Y)

58 I mentioned 'mainly' since some norms in the EU-Vietnam FTA are Vietnam specific, which most probably Vietnam put forward. E.g. EU Vietnam FTA, Ch. II, s. 1, Art. 3(3) - national treatment clause specific to Vietnam. 
that the stronger party will be willing to give up its own norms for the sake of some common norms. However, it could happen that in a future IIA between Vietnam and another party with similar power levels, Vietnam would use norms from the EU-Vietnam FTA that were inspired by EU norms. ${ }^{59}$ This could result in some form of involuntary diffusion of EU norms ('contagion'). Furthermore, if the EU concludes with weaker parties multiple bilateral agreements that are based on its own norms, then EU norm imposition/export shall occur on a broader scale. Such is the case for example with US or Canadian IIAs based on their model agreements.

In the second example a strong party with its own IIL norms is negotiating an agreement with a weaker party that has its own IIL norms. For example, in the case of CETA the EU is once again the 'stronger' party, with its own IIL norms. However, Canada as the 'weaker' party has previous model IIL norms of its own, in the form of foreign investment promotion and protection agreements (FIPAs) and the model FIPA. ${ }^{60}$ In such a case, the chances of Type A convergence are high, since both parties have existing norms and the weaker party will more likely follow the norms of the stronger one. In the case of CETA, Canada was willing to renegotiate the original 2014 version of the agreement in order to include the new EU model ICS. The chances for Type B convergence are lower, since the stronger party will be less willing to accept common norms if the weaker one can follow the norms suggested by it.

In the third example a strong party with its own IIL norms is negotiating an agreement with a strong party that also has its own IIL norms. For example, in the case of TTIP - the negotiations for which are currently frozen - both the EU and the US are 'strong' parties and both have their own 'model' IIL norms. Therefore, the chances of Type A convergence are quite small, since both parties will want to include part of their own norms. Thus, one can more or less talk about Type B convergence in this situation, since existing US and EU IIL norms would converge towards some form of common norms, provided an agreement is reached. Furthermore, an important bilateral agreement such as TTIP, between the two biggest world economies, could have become a vector for global norm distribution. One excellent example for this is NAFTA and how it became a 'trendsetter' for other PTAs with investment chapters. ${ }^{61}$ However, the possibility for the EU to

59 Governments sometimes rely on the models of other countries, which can have negative or even disastrous consequences. See T. Allee \& M. Elsig, Are the Content of International Treaties Copied-andPasted? Evidence from Preferential Trade Agreements 8, NCCR Working Paper (World Trade Institute, 2016), http://www.wti.org/research/publications/998/are-the-contents-of-international-treaties-cop ied-and-pasted-unique-evidence-from-preferential-trade-agreements/ (accessed 9 Apr. 2018).

60 See supra n. 9.

61 See F. Fontanelli \& G. Bianco, Converging Towards NAFTA: An Analysis of FTA Investment Chapters in the European Union and the United States, 50 Stan. J. Int'l L. 211-246 (2014); C. Lévesque, Influences on the Canadian FIPA and the US Model BIT: NAFTA Chapter 11 and Beyond, 44 Can. Y.B. Int'1 L. 249- 
become an IIL norm distributor via TTIP is on hold for the foreseeable future. Even prior to the current US Presidential Administration, both parties were finding it hard to agree on a commonly accepted investment chapter. Now, following the freezing of negotiations and the US' backtracking from major international economic agreements, the likelihood of some form of global norm distribution and norm convergence via TTIP is very small.

In conclusion, in the bilateral setting the EU has higher chances of exporting, imposing its own norms on weaker parties that may or may not possess IIL norms of their own; this can then lead to some level of Type A convergence. However, when faced with a stronger party with its own norms, the likelihood of Type B convergence on the bilateral level is higher, provided the parties reach a common agreement. Moreover, the possibility exists for such bilateral common norms to spill over to the multilateral field and induce further convergence on the multilateral level.

\subsection{INTERNAL CONSTRAINTS}

\section{3[a] A Discontent Civil Society and Rebellious Regional Parliaments}

When acting on the international level, the EU - similarly to states - must also take into consideration the needs of its domestic constituencies. The EU is a complex, multi-level machinery. On the vertical axis, the EU and the Member State level institutions influence the development of common policies and, as the Wallonian example ${ }^{62}$ illustrates (infra), the sub-national level has a say as well. On the horizontal level, the various EU institutions all play a role in policy development. Furthermore, one should not forget the input of civil society, NGOs, academics, etc.

Contrary to the EU's initial expectations, the inclusion of ISDS in the new FTIAs has sparked widespread public outrage. One just has to look at the 2015 anti-TTIP protests in Berlin, ${ }^{63}$ the open letter of over a hundred law professors against ISDS under the proposed TTIP, ${ }^{64}$ the rejection of ISDS by

298 (2006); W. Alschner et al., Text-as-Data Analysis of Preferential Trade Agreements: Mapping the PTA Landscape 5, UNCTAD Research Paper, UNCTAD/SER.RP/2017/5 (2017), http://unctad.org/en/ pages/PublicationWebflyer.aspx?publicationid=1838 (accessed 9 Apr. 2018). These authors conclude that many South-South PTAs also included NAFTA language.

62 S. Marks \& C. Oliver, Belgium's Wallons Cave on EU-Canada Trade Deal, Politico (27 Oct. 2016), goo. gl/5loNb5 (accessed 9 Apr. 2018).

63 The idea of ISDS was met with protests all around Europe, most importantly the massive rally in Berlin that gathered 250,000 people. See C. Johnston, Berlin Anti-TTIP Trade Deal Protest Attracts Hundreds of Thousands, The Guardian (Berlin 10 Oct. 2015), goo.gl/oTKmHd (accessed 9 Apr. 2018).

64 Legal Statement on Investment Protection and Investor-State Dispute Settlement Mechanisms in TTIP and CETA (Oct. 2016), goo.gl/nIXCcs (accessed 9 Apr. 2018). 
civil society during the EU Commission's 2015 public consultation, ${ }^{65}$ or the attempted 'sabotage' of the signature of CETA by the regional parliament of Wallonia.

The pressure coming from civil society in the end resulted in a reformed ICS that was subsequently included into CETA, even if the negotiations had ended and the parties had already agreed on a final text. This of course means that civil society only obtained a partial win; ISDS is still included in the new FTIAs with Canada, Vietnam and Singapore - albeit in a reformed way - and the EU can disseminate its new model ICS via these agreements.

One must not forget, however, the pressure that civil society can still put on Member State and/or regional governments to not conclude or ratify the new 'mixed' FTIAs. Three examples come to mind. In Germany, thousands of members of the German civil society initiated collective complaints before the German Federal Constitutional Court, concerning the ratification of CETA. ${ }^{66}$ The final decision of the German Court is still pending, but one of the preliminary decisions could lead to 'potential subsequent difficulties' in delimiting the trade competences between the EU and its Member States. ${ }^{67}$ In France, a large number of Members of the National Assembly asked the Conseil Constitutionnel to decide whether some of the provisions of CETA were unconstitutional. The Conseil ruled that CETA did not contain any unconstitutional clauses. ${ }^{68}$ The most well-known example is the Wallonian refusal to ratify CETA; the regional entity conditioned their approval of the agreement by having Belgium request an Opinion (1/17) from the Court of Justice on whether the ISDS mechanism under CETA is compatible with the EU Treaties, including fundamental rights. ${ }^{69}$

In conclusion, before the EU can become an IIL norm promoter, it first has to make sure that the new trade and investment agreements it seeks to conclude can/ will be ratified.

65 European Commission, supra n. 33.

66 See J. Miéral, The CETA, the German Federal Constitutional Court and the Distribution of Competences Between the EU and Its Member States, http://rsiblog.blogactiv.eu/2017/11/07/the-ceta-the-germanfederal-constitutional-court-and-the-distribution-of-competences-between-the-eu-and-its-memberstates/ (accessed 9 Apr. 2018).

67 Ibid.

68 Conseil Constitutionnel, Decision No. 2017-749 DC of 31 July 2017, http://www.conseil-constitu tionnel.fr/conseil-constitutionnel/francais/les-decisions/acces-par-date/decisions-depuis-1959/2017/ 2017-749-dc/version-en-anglais.149908.html (English version, accessed 9 Apr. 2018).

69 See Kingdom of Belgium, Foreign Affairs, Foreign Trade and Development Cooperation, Minister Reynders Submits Request for Opinion on CETA (6 Sept. 2017), registered as Opinion 1/17, https:// diplomatie.belgium.be/en/newsroom/news/2017/minister_reynders_submits_request_opinion_ceta (accessed 9 Apr. 2018). 


\section{3[b] The Court of Justice Might Have the Final Word}

The Court of Justice is a crucial internal player one cannot neglect. In 2017 and 2018 the Court brought several important changes that will affect the EU's investment law and policy, and its capacity to dissipate its norms externally.

First, the Full Court delivered its much-awaited Opinion 2/15 on whether the EU-Singapore FTIA should be concluded by the EU alone or together with its Member States, in the form of a mixed agreement. Even though the Court of Justice in the end opted for mixity, it greatly clarified the EU's external competences when concluding agreements covered by the CCP. Whilst it held that nondirect foreign investment and ISDS fell under shared competences, the Court greatly expanded the EU's exclusive external competences over all forms of services, public procurement, intellectual property, sustainable development and competition law. ${ }^{70}$ The Court also stipulated in several paragraphs that because parts of the EU-Singapore FTA fell under shared competences, it could not be approved 'by the European Union alone'. ${ }^{71}$ This made some academics wonder ${ }^{72}$ whether these paragraphs meant the end of 'facultative mixity', in the sense that the Member States had to participate in the conclusion of a trade agreement that included non-direct foreign investment and ISDS. Furthermore, Opinion 2/15 most probably prompted the Commission to pursue future trade agreements without investment chapters. ${ }^{73}$

Shortly after, in Germany v. Council (OTIF), the Court clarified that its aforementioned Opinion $2 / 15$ stipulations were specific to the facts of that case. ${ }^{74}$ This suggests that the Court did not wish to impose mandatory mixity if part of an agreement falls under shared competence. ${ }^{75}$ Thus, technically, the EU could conclude a trade agreement with investment protection and ISDS, by itself, without the participation of the Member States. However, the likelihood that the Member States would reach a political consensus to this end is quite low and they would most certainly want to participate in the conclusion of trade agreements with investment chapters.

70 CJEU Opinion 2/15, EU-Singapore FTA [2017] EU:C:2017:376. See Usynin \& Gáspár-Szilágyi, supra n. 48 .

71 Ibid., paras 244, 282, 304.

72 L. Ankersmit, Opinion 2/15 and the Future of ISDS and Mixity, http://europeanlawblog.eu/2017/05/ 18/opinion-215-and-the-future-of-mixity-and-isds/ (accessed 9 Apr. 2018).

73 S. Gáspár-Szilágyi, A Follow-up to the EU Commission's Decision to 'Split' Trade and Investment Protection, http://worldtradelaw.typepad.com/ielpblog/2017/09/guest-post-a-follow-up-to-the-eu-commis sions-decision-to-split-trade-and-investment-protection.html (accessed 9 Apr. 2018). Investment protection was also removed from the EU-Japan FTA.

74 CJEU, Council v. Germany (OTIF) [2017] EU:C:2017:935.

75 H. Lenk \& S. Gáspár-Szilágyi, Case C-600/14 Germany v. Council (OTIF). More Clarity over 'Facultative Mixity'?, http://europeanlawblog.eu/2017/12/11/case-c-60014-germany-v-council-otif-moreclarity-over-facultative-mixity/ (accessed 9 Apr. 2018). 
These two recent cases have important implications for the possibility of the EU to disseminate its own IIL norms, which in turn affects whether the EU can induce some form of normative convergence. If the EU opts to conclude a farreaching trade agreement without investment protection, then it can conclude the agreement as a sole-EU agreement, without the participation of Member States. The removal of the Member States and their regions from the ratification process will increase the chances of these agreements entering into force and the EU disseminating its norms. Nonetheless, these agreements would predominantly disseminate trade specific rules, not rules specific to IIL - such as investment protection standards or ISDS - since they would not include provisions on investment protection and ISDS. Thus, the EU would not be able to influence IIL norms via sole-EU trade agreements.

Furthermore, whilst the OTIF case seems to suggest that the EU can conclude a trade agreement with an investment chapter by itself - thus increasing the chances of a swift ratification of the agreement - it is unlikely that the Member States will agree to this. Thus, Member States and their regional parliaments would also need to ratify these agreements, prolonging or possibly blocking the ratification process. In other words, the dissemination of EU inspired IIL norms would be hindered.

Second, in March 2018 the Grand Chamber delivered its Achmea judgment $^{76}$ in which it held that Articles 344 and 267 TFEU preclude investor-state arbitration, 'such as' the one under the Netherlands-Slovak intra-EU BIT. In other words, investor state arbitration under intra-EU BITs is incompatible with EU law. Relying on Opinion 2/13, the Court argued that such tribunals affect the autonomy of the EU legal order, the principles of mutual trust and sincere cooperation, as well as the need to ensure the uniform and effective interpretation of EU law. These arguments make it highly likely that other ISDS mechanisms, such as the ICS under CETA, the MIC, and investorstate tribunals under existing Member State BITs, will also be incompatible with EU law. ${ }^{77}$ Furthermore, if the Court decides that the ICS under CETA is incompatible $^{78}$ with the EU Treaties and fundamental rights, then this will surely undermine the EU's future attempts to conclude trade agreements that include bilateral ICSs or a future MIC.

76 CJEU, Slowakische Republik v. Achmea BV [2018] EU:C:2018:158.

77 S. Gáspár-Szilágyi, It is Not Just About Investor-State Arbitration. A Look at Case C-284/16, Achmea BV, 3(1) European Papers 357-373 (2018). http://worldtradelaw.typepad.com/ielpblog/2018/03/guestpost-the-cjeu-strikes-again-in-achmea-is-this-the-end-of-investor-state-arbitration-under-intr.html (accessed 9 Apr. 2018).

78 S. Gáspár-Szilágyi, A Standing Investment Court Under TTIP from the Perspective of the CJEU, 17(5) J. World Inv. \& Trade 701-742 (2016). 
In conclusion, the recent (and future) developments in the Court of Justice's case law have the potential to seriously affect the EU's investment policy and its capacity to promote its IIL norms externally.

\section{CONCLUSIONS}

This article is meant to contribute to research in three ways. First, it aimed to contribute to the existing discussion on the ways in which the EU can export its norms externally. Second, the article also tried to provide a conceptual understanding of the often used term of 'convergence' and how the EU might induce some level of convergence of IIL norms, be it by the norms of other states moving towards EU norms or by putting forward commonly accepted norms that were influenced by its own norms. Third, it also meant to highlight the importance of looking at the EU's normative power in specific fields and not just broadly. Just because the EU might exert some form of normative force in bilateral trade or association agreements, does not yet mean that the EU will also be able to exert such force in IIL.

The article also has a sceptical undertone as to whether the EU can become an IIL norm promoter or contributor and whether it can induce some level of convergence of IIL norms. Whilst the possibility is there, the multilateral and diffused nature of investment law, the presence of strong international actors with their own agendas, the domestic contestation of ISDS, and the important role of the Court of Justice might hamper the EU's attempt to become a major influencer of IIL norms.

In light of these, the first question the Commission needs to ask itself is what areas of IIL can it influence. IIL is not just ISDS and the setting up of a permanent investment court; the UNCITRAL Transparency Rules and the Mauritius Convention are examples of improvements in investment law that can be achieved on the multilateral level with EU input. Efforts to more clearly draft investment protection standards can be another example. The second question is the more difficult one: how to bring about new changes and influence IIL norms? If the more immediate goal is to reform ISDS, the best advice is to wait for the outcome of Opinion 1/17, which will clarify the Court of Justice's attitude towards the ICS. Due to the contentious nature of ISDS, new trade agreements (see the negotiations with Australia, New Zeeland, or Japan) should not include investment chapters, so as not to jeopardize the overall trade agreement. Instead, 'anchor' clauses should be included in the trade agreements to pursue future agreements on investment protection, ${ }^{79}$ once the picture is clearer internally. In case the Court of Justice will opt for the incompatibility of the CETA ICS with EU law, the EU could still influence IIL norms, either bilaterally or multilaterally, by proposing alternatives to investor-state arbitration that might be more easily acceptable internally and externally.

79 Usynin \& Gáspár-Szilágyi, supra n. 48, at 295. 